\title{
Low productivity in the Critically Endangered Mauritius Olive White-eye Zosterops chloronothos
}

\author{
RINA K. NICHOLS, LANCE G. WOOLAVER and CARL G. JONES
}

\section{Summary}

Productivity of the endemic Mauritius Olive White-eye Zosterops chloronothos, the least known of the Mauritian land-bird species, was studied for three consecutive breeding seasons. Fifteen White-eye territories were monitored in 1998-1999 and 1999-2000, and 18 in 20002001. Although respectively $67 \%, 73 \%$ and $78 \%$ of pairs in these territories exhibited signs of breeding, the annual proportion of pairs that successfully produced a fledgling was found to be extremely low at $7 \%, 7 \%$ and $17 \%$ respectively. Only five fledglings were observed during the 3 year period. None of the pairs was observed to have more than one successful nesting episode per season, and no pair produced more than a single fledgling over the 3 years. The extremely low productivity of this declining population is of critical concern. Species-specific conservation management is urgently required for this species.

\section{Introduction}

Mauritius, with an area of $1,865 \mathrm{~km}^{2}$, is the second largest of the Mascarene Islands in the south-west Indian Ocean. Since the arrival of humans to Mauritius in the 1600 , over half the endemic vertebrate species have become extinct (Cheke 1987a). Mauritius Olive White-eye Zosterops chloronothos is one of eight threatened bird species remaining on the island (BirdLife International 2004) and is the least known of the endemic avifauna. It has been listed as Endangered (IUCN 2002) but has recently been upgraded to Critically Endangered by BirdLife International based on an extremely small and declining population, small range and declining habitat quality (BirdLife International 2004). The population has declined from an estimated 340-350 pairs in 1975 (Cheke $1987 \mathrm{~b}$ ) to 93-148 pairs in 2001 (Nichols et al. 2004). The main threats to the species are habitat loss, degradation of native forest, and intense nest depredation by introduced mammals. Less than $5 \%$ of native forest remains on Mauritius, in a very degraded state (Safford 1997a), and introduced Crab-eating Macaques Macaca fascicularis and Ship Rats Rattus rattus are a major cause of passerine nesting failures (Cheke 1987b, Safford 1997b).

Mauritius Olive White-eyes live singly or in pairs, travelling considerable distances in search of nectar sources. They have large non-exclusive home ranges but aggressively defend a small area around a favoured flower or nest-site against conspecifics and the more common, sympatric Mauritius Grey White-eye Zosterops borbonicus mauritianus (Cheke 1987b). Breeding biology observations have been extremely rare due to the species' low population, transient nature and elusive nesting habits (Cheke 
1987b, Safford 1991). Only eight nesting episodes have been documented for this species, seven of which were depredated by introduced mammals (one in Safford 1991, one found by R. Chevreau de Montléhu and published in Staub 1993, and five in Nichols et al. in press), and only one successful nest has been monitored (Nichols and Woolaver 2003). This study documents Mauritius Olive White-eye productivity within a high-density area of the species' range in 1998-2001.

\section{Methods}

Research was carried out at Combo, an area of $c .5 \mathrm{~km}^{2}$ within the Black River Gorges National Park of Mauritius (Figure 1). This area holds the highest known densities of Mauritius Olive White-eyes (Nichols et al. 2004). The breeding season of the Olive White-eye extends from September to March (Cheke 1987b, Safford 1991). This study was carried out from November to March in 1998-1999 and September to March in 1999-2000 and 2000-2001.

The proportion of monitored pairs that succeeded in producing a fledgling was used to describe the species' productivity. The number of pairs that produced a fledgling was divided by the number of pairs monitored for each season to calculate annual productivity.

Territories were monitored to determine the number of fledglings each pair produced over the 3 year study period. Territories within Combo were mapped following the methods of Safford (1997c). Territories were in the same location each year. Although not confirmed, it was suspected that the same pair used the same territory during the breeding season and in subsequent seasons as Mauritius Olive White-eyes are very territorial (Cheke 1987a, Safford 1991). Pairs were observed for signs of breeding, which included mutual preening, indications of a brood patch, one or both adults carrying nesting material or invertebrate food items, and one adult observed

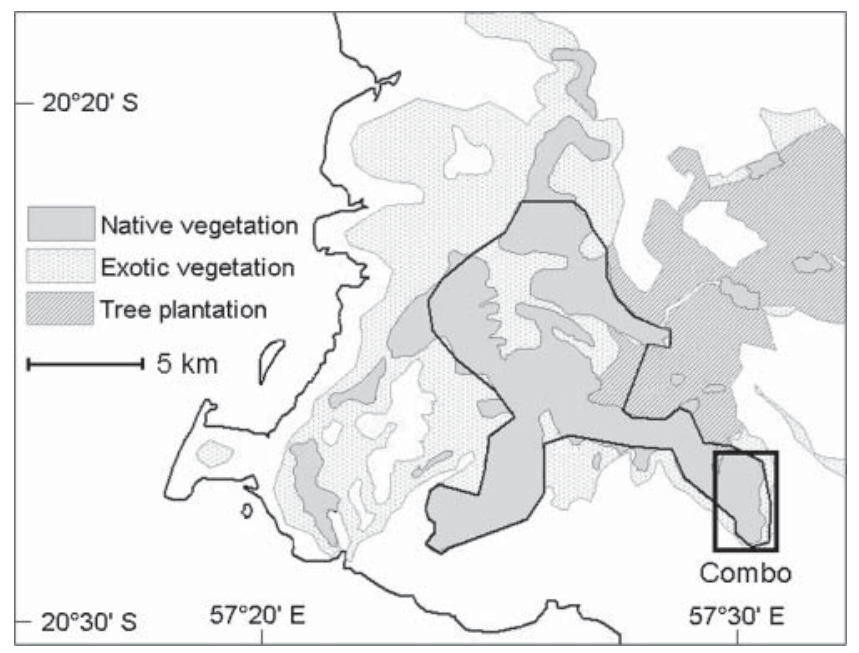

Figure 1. Map of south-west Mauritius with the Black River Gorges National Park (within the curved black line) and the area of Combo (within the black rectangle). Adapted from Safford (1997b). 
alone on more than two consecutive observations (suggesting the other adult was incubating). Due to the discreet behaviour of this species, it is possible that some pairs attempted to breed without being observed by us. Each territory was monitored one to three times per week with each pair being observed for $1-2$ hours per visit. This was sufficient to ensure the sighting of a fledgling with a pair since the young are dependent on the parents for 2 months after fledging (Nichols and Woolaver 2003).

\section{Results}

Fifteen territories were monitored in 1998-1999 and 1999-2000, and 18 in 20002001. The same 15 territories were monitored over the three breeding seasons with an additional three territories monitored in 2000-2001. Over the three seasons, $67 \%$, $73 \%$ and $78 \%$ respectively of the monitored pairs were seen to exhibit signs of breeding (Table 1). Of those breeding pairs, 10\%, 9\% and 21\% respectively were successful in producing a fledgling (Table 1 ). Overall productivity, as represented by the proportion of all monitored pairs successful in producing a fledgling, was $7 \%$ in 1999, 7\% in 2000 and $17 \%$ in 2001 (Table 1 ).

A total of five single fledglings were sighted during the 3 year study period, in five separate territories. Given the species' territoriality, this strongly suggested that five different pairs produced the fledglings and that no pair produced more than one fledgling during the 3 year period. One fledgling was observed in each of the first and second seasons and three fledglings were observed in the third season. The number of fledglings produced per pair per year over the 3 year period was O.Io ( 5 fledglings/ 48 pair-years).

\section{Discussion}

The low productivity of Mauritius Olive White-eye is of critical concern. The population continues to decline rapidly with at best around 150 pairs remaining (Nichols et al. 2004), and the long juvenile dependency period (Nichols and Woolaver 2003) limits the number of young that can be produced per season.

Only $7-17 \%$ of pairs were successful in producing a fledgling over the 3 year period and only one of the eight ( $12 \%$ ) nests recorded for this species has been successful. As a comparison, the Critically Endangered Seychelles White-eye Zosterops modesta on Conception Island has an apparent nesting success greater than $40 \%$, with the majority of pairs producing fledglings each season (Rocamora and François 2000). Even on the island of Mahé, where the Seychelles White-eye population is dwindling

Table 1. Productivity of Mauritius Olive White-eyes in Combo between 1998 and 2001.

\begin{tabular}{lccc}
\hline & $1998-1999$ & $1999-2000$ & $2000-2001$ \\
\hline Pairs monitored & 15 & 15 & 18 \\
\hline No. (\%) of pairs seen to exhibit signs of breeding & $10(67 \%)$ & $11(73 \%)$ & $14(78 \%)$ \\
$\begin{array}{l}\text { No. (\%) of pairs seen to exhibit signs of breeding that } \\
\text { produced a fledgling }\end{array}$ & $1(10 \%)$ & $1(9 \%)$ & $3(21 \%)$ \\
No. (\%) of all monitored pairs that produced a fledgling & $1(7 \%)$ & $1(7 \%)$ & $3(17 \%)$ \\
Total no. of fledglings produced by all pairs combined & 1 & 1 & 3 \\
\hline
\end{tabular}


and has an apparent nesting success of $13 \%$, the majority of breeding pairs still succeed in producing young (G. Rocamora in litt. 2003). On Heron Island in Australia, $60 \%$ of territorial pairs of the Capricorn Silvereye Zosterops lateralis chlorocephala produced fledglings each year (Catterall et al. 1982). Although productivity of the common and sympatric Mauritius Grey White-eye has not been documented, fledglings were frequently observed in the Black River Gorges National Park between 1998 and 2001 (R. Nichols and L. Woolaver pers. obs.).

Only single fledglings were produced by each pair of Mauritius Olive White-eye. In 1975, Cheke (1987b) observed three family units of three "sometimes with one bird begging". Although he was unable to confirm these were adults with fledglings, "one bird begging" still suggests only one fledgling. This indicates that breeding pairs do not commonly fledge more than one young, and have not for several decades. Pairs in the declining populations of Seychelles White-eye most commonly produce one fledgling per successful nest, but will occasionally produce two or three fledglings (Rocamora and François 2000). Since little previous data exist for Mauritius Olive White-eye it is not known whether single fledglings were common in the past or whether some current factor, such as reduced food availability from habitat degradation, is negatively affecting brood size or number of young that fledge. Clutches of two and three eggs were reported in the early 1900s, but unfortunately the number of fledglings was not documented (Cheke $1987 \mathrm{~b}$ ). Carié (cited in Cheke 1987b) noted "little groups of four or five" that were seen to separate very soon after fledging. This suggests that Olive White-eyes may at one time have been able to produce more than one fledgling, although the latter part of Carié's observation does not concur with the long juvenile dependency period of 2 months for this species (Nichols and Woolaver 2003).

None of the breeding pairs was observed to have more than one successful nesting episode per year. If this study is representative of the productivity of the entire population, the $7-17 \%$ of pairs that are able to produce a fledgling will most likely fledge only one young per year. Using the most recent population estimates, this suggests that $11-26$ pairs $(7-17 \%$ of 150 pairs) are producing fledglings each year. A recruitment of $11-26$ young per year for a declining passerine population is exceedingly low. Simulation modelling of population data for Mauritius Fody Foudia rubra revealed that populations in which $20 \%$ or less of pairs reared one brood with no supplementation from a source population declined sharply to extinction (Safford 1997d).

\section{Conservation needs}

Ecological research on Mauritius Olive White-eye should be of high priority and is required for effective conservation. Most importantly, reproductive success in relation to habitat and to predator and competitor densities should be investigated so that management techniques can be developed to increase productivity in the wild population.

Nest predation by introduced predators has played a significant role in the decline of Mauritian passerines (Cheke 1987b). Seven of the eight nesting episodes documented for Mauritius Olive White-eye have failed due to depredation by Ship Rats (five in Nichols et al. in press), and Crab-eating Macaques (one in Safford 1991, one in Staub 1993). Introduced Ship Rats are considered a major threat to seven of the 14 island Zosterops species in danger of extinction and are suspected to have been the 
main cause of extinction of Robust White-eye Zosterops strenuus (BirdLife International 2004). Conservation management should include increasing productivity of wild pairs by protecting critical breeding areas from Ship Rats and Crab-eating Macaques using predator-specific methods of control such as live-trapping or poisoning (Jones et al. 1992), and by predator-proofing individual nest-sites (Hamel and McLean 1989, Malham et al. 2002).

Translocating individuals or pairs to rehabilitated predator-free offshore islets (Safford and Jones 1998), which has recently been done successfully for Seychelles White-eye (Rocamora et al. 2003), may prove successful in increasing productivity for Mauritius Olive White-eye. Captive breeding of pairs in release enclosures in the native forest, with the soft release of young into the natal area (Nichols et al. 2004), may also prove cost-effective and increase productivity. Species-specific management aimed at increasing the number of young successfully fledged by wild pairs, in addition to large-scale habitat protection and rehabilitation, is urgently required for the survival of Mauritius Olive White-eye.

\section{Acknowledgements}

The Ruth Smart Foundation (U.K.), the United Emirates Natural History Group and the Durrell Wildlife Conservation Trust provided financial support for the passerine research on Mauritius. The cooperation of the National Parks and Conservation Service of Mauritius and the continued support of Mr Yousoof Mungroo were greatly appreciated. Many dedicated volunteers and staff of the Mauritian Wildlife Foundation assisted during fieldwork, with Thomas Bodey, Malcolm Burgess, Angela Duffy, Sally Fisher and Malika Virah-Sawmy all providing significant contributions. Richard Lewis deserves special acknowledgement for his contribution during the first season of this study. Gérard Rocamora, Anthony Cheke and Roger Safford provided valuable comments on earlier drafts of this manuscript.

\section{References}

BirdLife International (2004) Threatened birds of the world 2004. CD-ROM. Cambridge, U.K.: BirdLife International.

Catterall, C. P., Henderson, L. J. and Wyatt, W. S. (1982) Food resources, territory density and reproductive success of an island silvereye population Zosterops lateralis. Ibis 124: 405-421.

Cheke, A. S. (1987a) An ecological history of the Mascarene Islands, with particular reference to extinctions and introductions of land vertebrates. In Diamond, A. W., ed. Studies of Mascarene Island birds. Cambridge, U.K.: Cambridge University Press.

Cheke, A. S. (1987b) The ecology of the smaller land birds of Mauritius. In Diamond, A. W., ed. Studies of Mascarene Island birds. Cambridge, U.K.: Cambridge University Press.

Hamel, R. D. and McLean, I. G. (1989) Caging as a technique for rearing wild passerine birds. J. Wildl. Manag. 53: 852-856.

IUCN (2002) 2002 IUCN red list of threatened species. Gland, Switzerland: International Union for the Conservation of Nature and Natural Resources Species Survival Commission.

Jones, C. G., Swinnerton, K. J., Taylor, C. J. and Mungroo, Y. (1992) The release of captive-bred Pink Pigeons Columba mayeri in native forest in Mauritius. Dodo 28: 92-125.

Malham, J., Bodey, T., Reauleaux, A. and Kent, G. (2002) Management of the Echo Parakeet in the wild, 2001/2002. Unpublished report to the World Parrot Trust, Loro Parque, Durrell Wildlife Conservation Trust, National Parks and Conservation Service of Mauritius and Mauritian Wildlife Foundation. 
Nichols, R. K. and Woolaver, L. G. (2003) First observations of a successful nest for the endangered Mauritius Olive White-eye Zosterops chloronothos. Bull. Afr. Bird Club 10: 101-106.

Nichols, R. K., Woolaver, L. G. and Jones, C. G. (2004) Continued decline and conservation needs of the endangered Mauritius Olive White-eye Zosterops chloronothos. Oryx 8: 291-296.

Nichols, R. K., Woolaver, L. G. and Jones, C. G. (in press) Breeding behaviour of the endangered Mauritius Olive White-eye Zosterops chloronothos. Ostrich.

Rocamora, G. and François, J. (2000) Seychelles White-eye Recovery Program. Phase I (May 1998-May 2000). Final report. Republic of Seychelles, Indian Ocean: Ministry of Environment and Transport/IUCN/Dutch Trust Fund.

Rocamora, G., Henriette, E. and Constance, P. (2003) Successful conservation introduction of the Seychelles White-eye on Frégate Island, Seychelles. Reintroduction News, Newsletter of the Re-introduction Specialist Group of IUCN's Species Survival Commission 22: 46.

Safford, R. J. (1991) Status and ecology of the Mauritius Fody Foudia rubra and Mauritius Olive White-eye Zosterops chloronothos: two Mauritian passerines in danger. Dodo 27: 113-138.

Safford, R. J. (1997a) A survey of the occurrence of native vegetation remnants on Mauritius in 1993. Biol. Conserv. 80: 181-188.

Safford, R. J. (1997b) Nesting success of the Mauritius Fody, Foudia rubra, in relation to its use of exotic trees as nest sites. Ibis 139: 555-559.

Safford, R. J. (1997c) Distribution studies on the forest-living native passerines of Mauritius. Biol. Conserv. 80: 189-198.

Safford, R. J. (1997d) The destruction of source and sink habitats in the decline of the Mauritius Fody, Foudia rubra, an island-endemic bird. Biodiv. Conserv. 6: 513-527.

Safford, R. J. and Jones, C. G. (1998) Strategies for land-bird conservation on Mauritius. Conserv. Biol. 12: 169-176.

Staub, F. (1993) Fauna of Mauritius and associated Flora. Mauritius. Précigraph Limited.

RINA K. NICHOLS

Mauritian Wildlife Foundation, Avenue Bois des Billes, Black River, Mauritius, Indian Ocean. Present Address: Wildlife Preservation Trust Canada, 120 King Street, Guelph, Ontario, Canada, $\mathrm{N}_{1} \mathrm{H}_{4} \mathrm{P} 8$.

\section{LANCE G. WOOLAVER}

Mauritian Wildlife Foundation, Avenue Bois des Billes, Black River, Mauritius, Indian Ocean.

Present Address: Wildlife Preservation Trust Canada, 120 King Street, Guelph, Ontario, Canada, N1E4P8. (e-mail: lancewoolaver@hotmail.com)

CARL G. JONES

Mauritian Wildlife Foundation, Avenue Bois des Billes, Black River, Mauritius, Indian Ocean.

Received 29 December 2003; revision accepted 6 December 2004 